\title{
Ambiances
}

anbiances Environnement sensible, architecture et espace urbain Varia | 2019

\section{Humanizing the robot: Kaliningrad's House of Soviets and the state of decay}

Humaniser le robot : la maison des soviets de Kaliningrad et l'état de décomposition

Michael Amundsen

\section{(2) OpenEdition}

Journals

Electronic version

URL: http://journals.openedition.org/ambiances/2053

DOI: 10.4000/ambiances.2053

ISSN: 2266-839X

Publisher:

Direction Générale des Patrimoines - DAPA - MCC, UMR 1563 - Ambiances Architectures Urbanités (AAU)

\section{Electronic reference}

Michael Amundsen, «Humanizing the robot: Kaliningrad's House of Soviets and the state of decay », Ambiances [Online], Varia, Online since 14 January 2019, connection on 19 April 2019. URL : http:// journals.openedition.org/ambiances/2053; DOI : 10.4000/ambiances.2053

This text was automatically generated on 19 April 2019

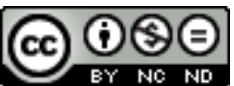

Ambiances is licensed under a Creative Commons Attribution-NonCommercial-NoDerivatives 4.0 International License. 


\title{
Humanizing the robot: Kaliningrad's House of Soviets and the state of decay
}

\author{
Humaniser le robot : la maison des soviets de Kaliningrad et l'état de
}

décomposition

Michael Amundsen

I've got you under my skin / I've got you deep in the heart of me / So deep in my heart, that you're really a part of me / I've got you under my skin. (Frank Sinatra, From Cole Porter) ${ }^{1}$

Well, the House of Soviets I have come to like somewhat. It wouldn't be Kaliningrad without it. (Maria, born and raised in Kaliningrad)

\section{Introduction}

When the architect Yulian Shvartsbreim was commissioned to construct a building for the regional administration of Kaliningrad oblast, he envisioned something grand and imposing, a building that called for focused vision and a political context asserting dominance. This is indeed what he created, but the ultimate outcomes have been unexpected. Begun in 1970, the House of Soviets was created as a modernist, brutalist work of concrete suggesting science fiction. If we can speak of architecture as a defense against the terror of space, we must also recognize that from the very beginning it was a defense against the terror of time (Harries,1982). Shvartsbreim's building was intended as just that, a modernist structure outside of space and time that reflected the timeless socialist values of the Soviet state. However, the building was never finished or put to use. As the project dragged along, the foundation was discovered to be unstable, and sinking into the marshy land very close to where the Königsberg Castle had stood when this city was the capital of East Prussia, and before Soviet authorities removed it in 1960. The House of Soviets was designed as a kind of riposte to the "fascist" structure preceding it. The project was abandoned in the 1980s and has sat empty ever since. 
2 When the Soviet Union began its administration of Königsberg, calling it Kaliningrad and evicting the German population, the city centre was destroyed during bombing attacks, a siege and the battle that ensued at the conclusion of World War II. For practical reasons, Kaliningrad developed as suburbs, leaving the centre empty. This is still largely the case today, as the centre has proved difficult to plan and create. The House of Soviets is located here and is an aspect of the planning problems faced by the city's administrators. The centre of Kaliningrad can be appreciated as an example of post Soviet urban blight, muddled and ringed by concrete apartment blocks undergoing structural decay.

3 The House of Soviets then has the obvious quality of a failed building created by a dysfunctional and now obsolete state. It therefore stands for the Soviet Union, defunct and swept into the dustbin of history. Yet, this building persists and there are still no plans to remove it. Its prominent position in the city means that it is visible from many vantage points around the centre. It strongly influences and creates atmospheres of feeling and memory, both personal and collective. In large part because of its sheer size and location, the House of Soviets is a metonymy for Kaliningrad. Like the Golden Gate Bridge or the Eiffel Tower, when you see this building you know where you are.

This fact imparts special qualities to the House of Soviets. No matter where a person grows up, there is some affinity for a place where someone spent their formative years, developed relationships and spent important moments. Clearly, not all childhoods are happy and not all places are wonderful, but that does not discount this affinity. We also know that people take pride in coming from difficult circumstances, the wrong side of the tracks or a rough neighborhood. This denotes authenticity of both place and person. The House of Soviets, derided as an aesthetic disaster, is also a part of people's lives.

5 Apropos of authenticity, the building, as a ruin, is a reminder of the passage of time and the ephemerality of the material world. It therefore suggests our human predicament as beings with finite lives and bodies that decay. The built ruin is the most obvious counter image to an architecture that seeks to defeat the terror of time through comforting images of permanence (Harries, 1982). The House of Soviets is a compelling example of dialectic process. Created as a modernist behemoth, carved out of empty space and standing in contrast to the necessity of time, it has succumbed to both its spatial and temporal limitations, and in doing so has become something else.

6 The House of Soviets is an expression of what constitutes home for Kaliningrad's residents. As it falls apart, it is also a reminder of human frailty and failure. The apartment blocks, which surround Kaliningrad, too, are concrete and falling apart. The city centre, with its cracked sidewalks and feral dogs running around, finds its architectural expression in the House of Soviets.

7 Though this building was designed to engage focused vision and project definite ideas about the state, its omnipotence and omnipresence in the lives of citizens, this article argues that it is best understood through the peripheral vision of atmospheres articulated by Juhani Pallasmaa and others. This takes into account the building's ensemble qualities, its environment and the embodied experiences of subjects who engage with it.

8 This article tries to answer questions about what this building means for those in its presence. What does such a prominent structure mean in its current context? How does it engage with embodied experience, the inside and outside of human sensibilities? What sort of atmospheres and emotions does the House of Soviets engender? 
9 To answer these questions, I undertook an afternoon of urban exploration on 2 May, 2013 with two Kaliningrad residents in the building. Having seen this edifice over many visits to Kaliningrad over the years, it was compelling and exciting to enter the House of Soviets through this informal method.

10 Theoretically, this article engages with Pallasmaa's idea of "sixth sense" and with current scholarship on architectural atmospheres and embodied encounters with the built environment. It attempts to find a human dimension to the "robot", and in so doing discovers that the building is not so inhuman after all. The House of Soviets is turning into something "else", moment by moment, its becoming altering subjective notions of aesthetics, material and time.

\section{Sixth sense, atmospheres, and ruins}

11 The quality of a space or place is not merely a visual perceptual quality, as it is usually assumed (Pallasmaa, 2014). Juhani Pallasmaa, an architect and leading philosopher of architecture from Finland, has explored how the human sensorium engages with space holistically; how the eyes "feel" and the skin "sees". His critique of much modern architecture is that it promotes "focused vision" which leaves the subject outside the experience of space and promotes the experiential poverty of contemporary settings.

Historically, the fundamental task of architecture was to create a harmonic resonance between the microcosm of the human realm and the macrocosm of the Universe (Pallasmaa, 2016). The industrial man changed this equation whereby utility, technique and visual aesthetics inform how buildings are made. The emphasis on vision has come at the cost of the other senses leaving the subject outside the full experience of space.

The Soviet Union had many architectural styles, some quite appealing and aesthetically welcoming. However, modernist Soviet architecture from the mid-20 $0^{\text {th }}$ century through the 1980s, relied on imposing structures engaging focused vision. The psychological effect of such structures leaves the human diminished, in the political context, as a subject not a citizen. The massive size of many of these buildings promotes an aura of omnipotence and panoptical intimidation. Kaliningrad's House of Soviets was created as just such a structure. The "robot", a machine of the state, was where the state's functionaries were to carry out their orders.

It is not surprising that such a building could be regarded as "soulless" and lacking in human warmth. But the problems exuded in the design of the House of Soviets were found the world over in buildings, which attempted to engage primarily with vision and form. The notion of atmospheres was largely ignored in such structures.

Atmospheres, applied to urban and other spatial settings, denote feelings engendered in space. All the senses, including sight, are extensions of the sense of touch: the senses are specializations of the skin, and all sensory experiences are related to tactility (Pallasmaa, 2012). In this way, we feel the atmosphere of space in very real ways. Atmospheres enhance and create moods and are closely allied to affects. Affects impact humans involuntarily and unconsciously and can be precursors of emotions and constituent parts of atmospheres. Affect is "a transpersonal capacity which a body has to be affected (through an affection) and to affect (as the result of modifications)" (Anderson, 2006, p. 735). Atmospheres radiate effects that are largely shared (Griffero, 2013). However, atmospheres are not merely passively received and can be seen to be co-created from the 
individual, the group and the setting. The properties of atmospheres capture the intersection between the objective and the subjective (Edensor \& Sumartojo, 2015).

Atmospheres are the "sixth sense" of architecture. Diffuse and peripheral vision, unconscious and embodied, is the normal way humans interact with the environment. Touch is the parent of our eyes, ears, nose, and mouth. It is the sense which became differentiated into the others, a fact that seems to be recognized in the age-old evaluation of touch as "the mother of the senses" (Montagu,1986, p. 17). Our culture of control and speed has favoured the architecture of the eye, with its instantaneous imagery and distant impact, whereas haptic architecture promotes slowness and intimacy, appreciated and comprehended gradually as images of the body and the skin (Pallasmaa, 2000).

Conventional western notions of the senses have been shown to be arbitrary, broken down to Aristotle's notion of five senses, but subject to change in different contexts. In the middle ages, it was common to regard speech as a sense (Howes, 2009). Other cultures have completely different notions of the senses whereby organs and body parts are repositories of knowledge. The Cashinahua of Peru conceive the hands, the ears, the genitals and the eyes as knowledge centers for different activities. Skin knowledge is knowing about the environment learned through the affects of wind, sun, rain and the forest (Howes, ibid.). In the classical world, the senses were understood as a media of communication rather than passive receptors. Humans have commonly understood sensory perceptions as an embodied engagement with the environment, which is integrated and not separated into different functions.

The judgment of environmental character is a complex multi-sensory fusion of countless factors, which are immediately and synthetically grasped as an overall atmosphere, ambiance, feeling or mood (Pallasmaa, 2014). Architects of the modern era have often disregarded atmospheres, ambiances and feelings as something naïve, romantic, and entertaining, instead of seeing them as necessary constituents of environmental quality.

Ruins of buildings, whatever the original composition and architectural intention, engage with the senses holistically. Even if they were imposing modernist buildings like the House of Soviets, their decomposition and neglect impart sensory affects far more complex than focused vision. Ruins remind us of impermanence and can provoke estrangement, longing and imagination. A ruined structure derives its power and promise from its refusal to be assimilated in the surrounding symbolic order (Schonle, 2006). Ruins can also elicit feelings of yearning, melancholy and a romantic affinity with an imagined past (Simmel, 1959).

Purposeless spaces create tension and uncertainty in the built environment. Modern ruins are just such spaces. They are open to interpretation, both aesthetically and functionally. Often obscure in function and value, objects in ruins speak back to a material world in which things are contained by assigned places and normative meanings (Edensor, 2005).

21 Exploring ruins unlocks their potentials. Entering a ruin through the practice of urban exploration (UE) embraces the senses. In a Pallasmaanian understanding of an embodied sense of space, a ruin can be a more "successful", or at least more engaging, space than a modernist building that works to capture fixed vision. Focused vision and static gaze are "exceptional conditions in the reality of life" (Pallasmaa, 2016, p.2). The ruined form brings the modernist structure back down to earth from Le Corbusier's notion of architecture as "the masterly, correct and magnificent play of masses brought together in 
light" (Le Corbusier, 1923, p. 16)². This Apollonian conception can be beautiful, majestic and imposing, but it leaves out the human subject, who is directed only to gaze up at its splendor.

Socialist ruins as sites of everyday life are imbued with feelings by citizens who have lived with them as places of work or backdrops to their personal world. The urban ruin is therefore often a site of nostalgia for something lost. Their recent vintage means that they can only be interpreted as phenomena coeval with the people around them. Urban ruins as places of memory and feeling immediately reduces the perception of dilapidated structures as mere material garbage waiting for dynamite or some form of salvage. This nostalgia cuts through political ideology, longing for personal union with a different time. In a broader sense, this nostalgia is rebellion against the modern idea of time, history and progress (Boym, 2001).Ruins provoke the imagination of the viewing subject to consider the past, but also the potential divergent futures envisioned by their creators which did not come to pass. The ruin's contingent stories often emerge at the interface between personal and collective memory, as material remains mediate between history and individual experience (De Silvey \& Edensor, 2012).

\section{Exploring the House of Soviets}

Urban exploration (UE) can expand the possibilities of the senses. Sensual experiences tend to be minimized by regulatory procedures, planning, cultural conventions and values and spatial divisions (Edensor, 2007). The urban ruin is ripe for novel sensory experience. Their very status as closed spaces means they are seldom experienced by human intervention. The city can therefore be experienced as more than what it is commonly held to be. These spaces stand outside the familiar, comfortable and sensory routine. While such sites are frequently vilified as despondent realms, spaces of waste and blights on the landscape, they support a range of human activities and a plethora of nonhuman life forms, as well as offering aesthetic, somatic and historical experiences at variance to the often over-coded, themed spaces of urban renewal (Edensor, 2008). 
Illustration 1: House of Soviets

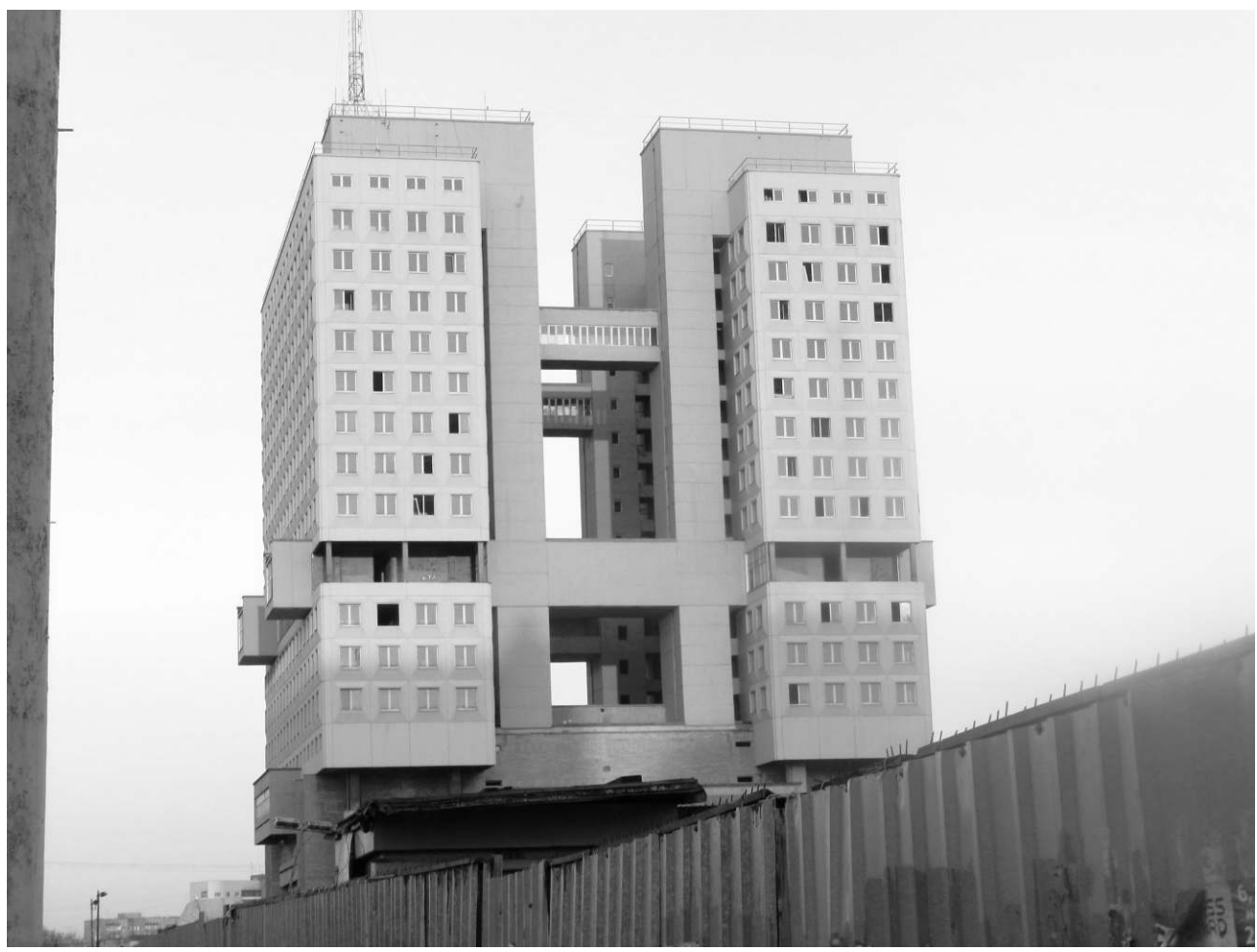

Source and copyright: (c) Michael Amundsen

This promoted an atmosphere of anticipation. As we entered the ground floor, Maria overturned a woodpile and exclaimed, "It's like an open-air museum." Indeed, for the two residents of Kaliningrad, our exploration of the building was a close encounter with an important component of the built environment that has impacted their lives from their earliest years. The building seen from its exterior projects an atmospheric aura and panoptical quality associated with its Soviet heritage. This aura suggests a strange weave of space and time in a city whose various iterations are embedded in the landscape. In this sense, entering and investigating the House of Soviets provided the giddy thrill of children passing through a haunted house. Although the building engenders atmospheres of sadness and loss, walking through its gray, empty and dirty rooms, our sense of expectation imparted joy and thus color in the midst of absence. Atmospheres are always located in-between experiences and environments (Bille, Bjerregaard \& Sørensen, 2015). An atmosphere of decrepitude mingled with the mood of discovery.

The general pattern of our exploration was to ascend the stairs of the building, stopping here and there when something of interest cropped up. It was clear that visitors in the House of Soviets were common. The building was strewn with beer and liquor bottles and 
graffiti. It did not appear, however, to be an encampment for the homeless. Our mood was heightened by anticipating the view from the roof of the building. Veronika noted, "I can't wait to see the city from the top."

Climbing the concrete stairs of the House of Soviets, the senses are drawn to the empty rooms, covered in dust and debris, but also outside, to Kaliningrad. It occurred to me that I was appreciating the city in ways that were uncommon. With each step, new feelings opened up. The imagination was kindled, excitement and an appreciation of the necessity of time were confronted. The quality of "unlocking the city" associated with the UE ethos became apparent (Garret, 2013). To feel the center of Kaliningrad on foot is to walk along its wide boulevards of crumbling pre-fabricated housing, broken sidewalks and trafficfilled streets. Ascending the House of Soviets opened up the cityscape, showing the relationship between the layered strata of its past and current iterations; German, Soviet and Russian.

The stairs and floor were frequently strewn with debris, forcing a measured and careful stride, akin to hiking in wilderness. There is a strong, musty odor in the House of Soviets which the labored breathing from climbing stairs promotes appreciating. The prevalence of asbestos in the building made deep breathing less desirable and encouraged small breaks on the climb upstairs.

Illustration 2: Asbestos

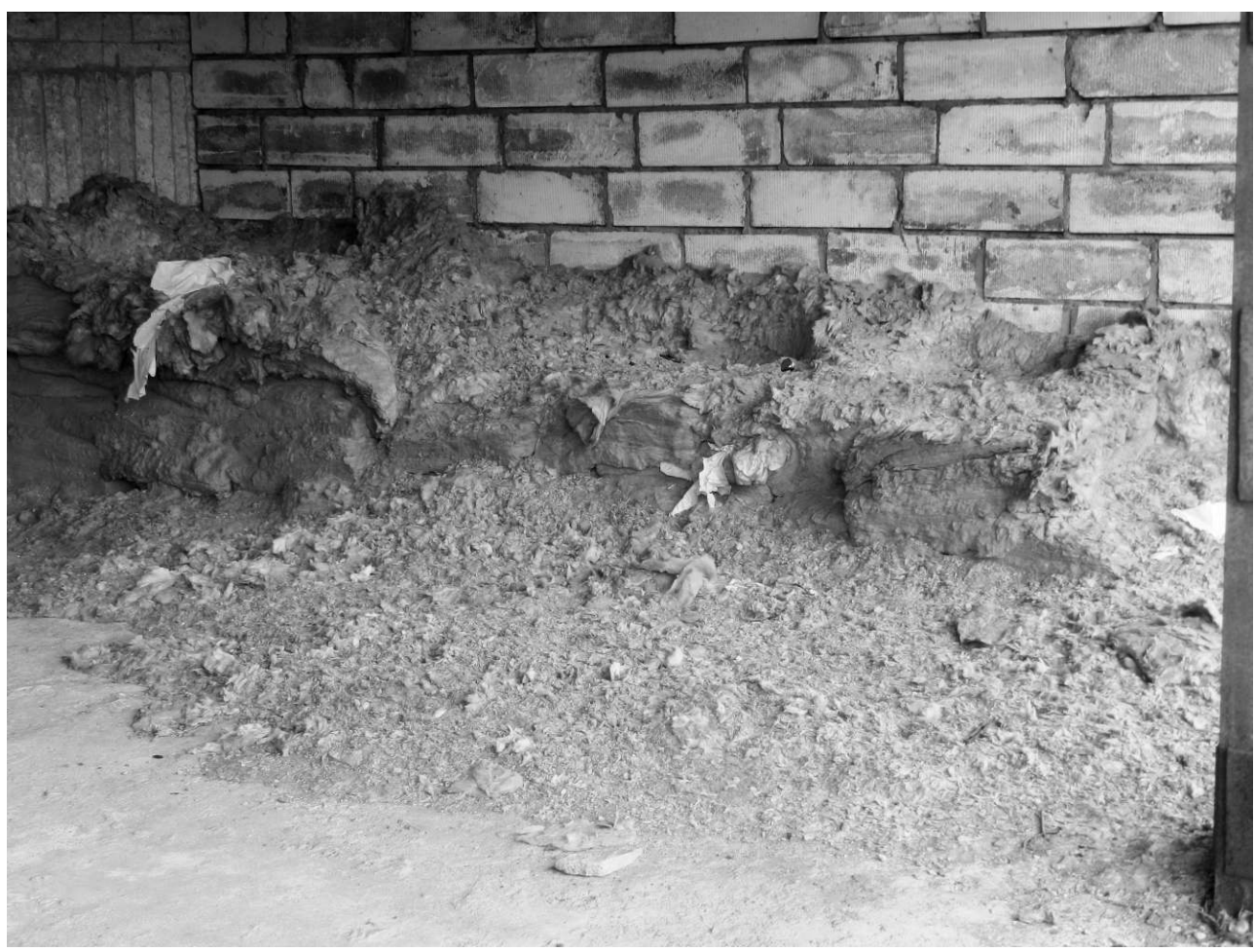

Source and copyright: @ Michael Amundsen.

Climbing up the building, its geometric design is evident and striking. As the House of Soviets is really two attached structures, it is the side of each building facing inward, a view outside of the public gaze, which reveals its most appealing aspect. Here, one can appreciate the architect's vision for the everyday milieu of the House of Soviets' 
workforce; the people that never came. There is a salient sense of absence in the building and melancholy for the plans that came to naught.

Illustration 3: Shattered windows

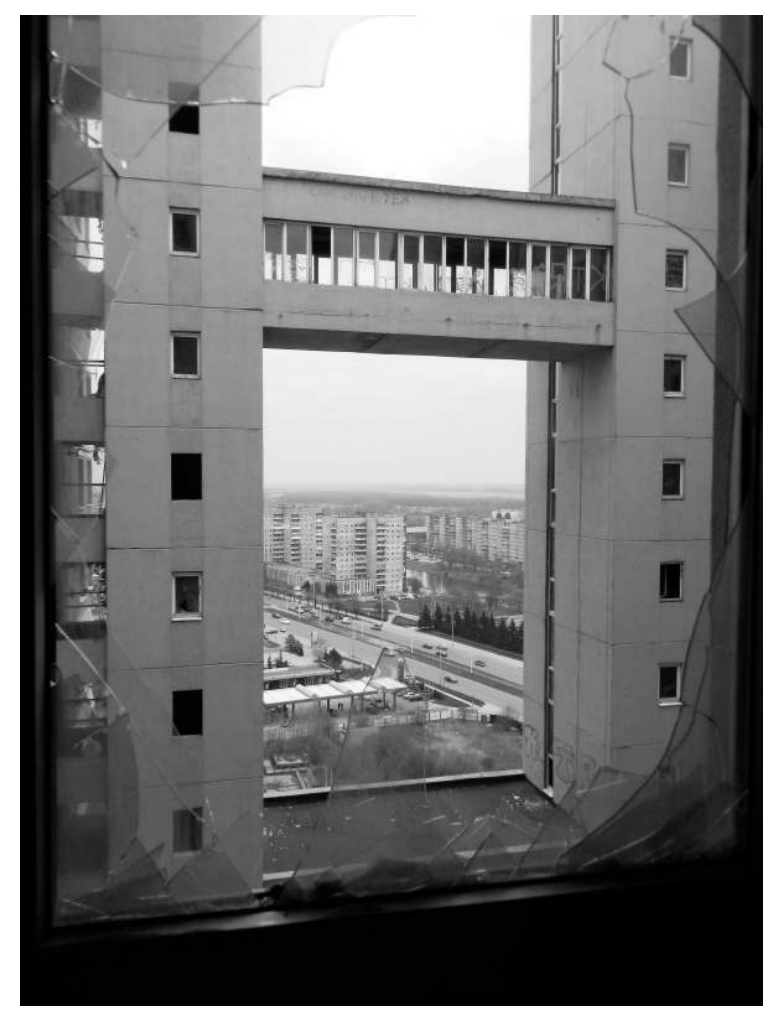

Source and copyright: (C) Michael Amundsen

On the top floor of the House of Soviets sits its nerve center, a cabinet of electronic gadgetry, which has been pillaged. It seems to have been the system intended to control electricity, lighting and any other aspects of the mechanical workings of the building. The doors of the cabinet have been thrown open, one of them is off its hinges. There is a fivepointed star painted in the center of one of the doors. Is it a Soviet star? An ironic commentary on a collapsed state, architectural failure and obsolescent ideological symbolism? Only the graffiti artist knows for certain, but it is an apposite figure that adds to the haunted quality of the House of Soviets. 
Illustration 4: Pillaged machinery

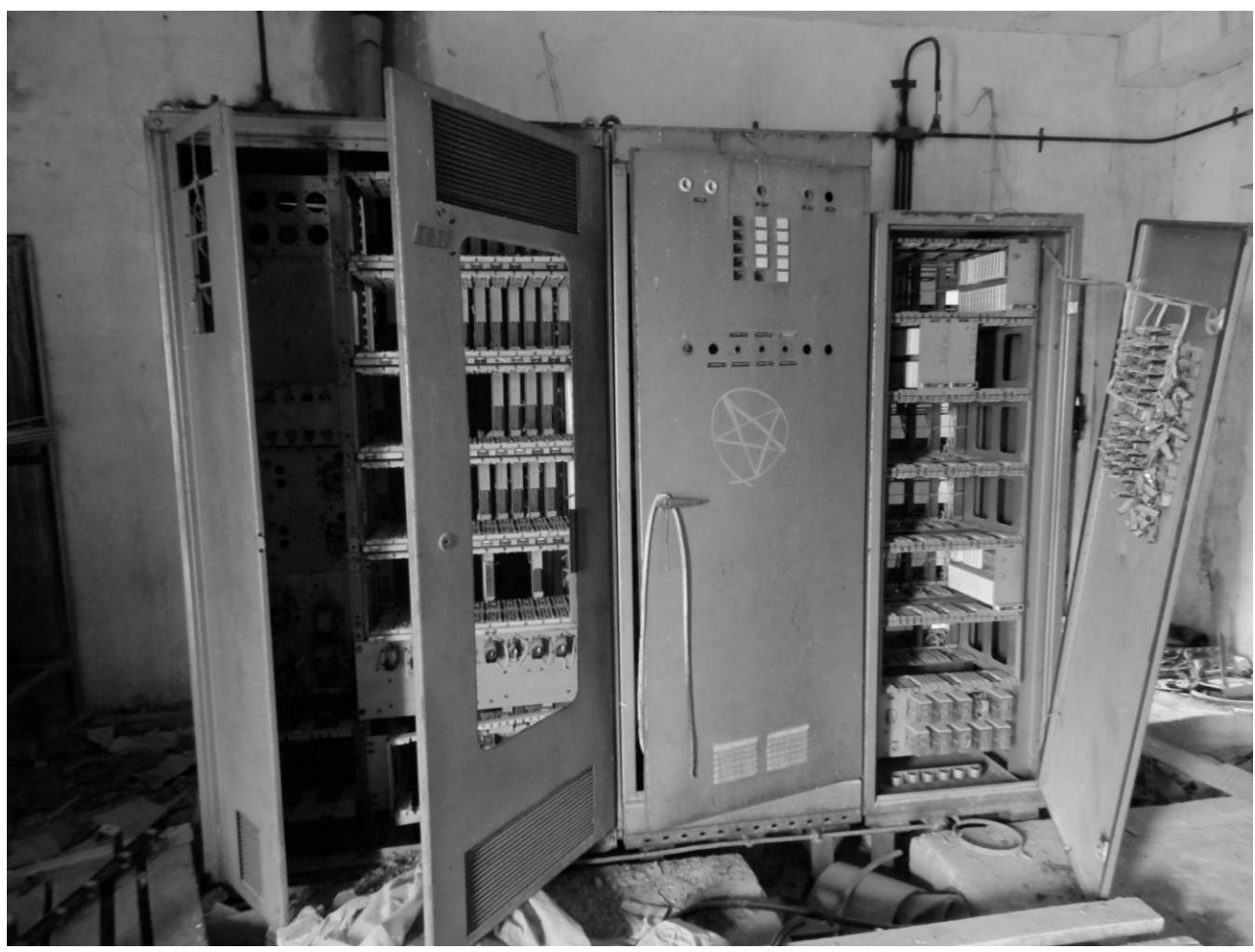

Source and copyright: @ Michael Amundsen

31 The roof of the House of Soviets reveals a hidden city; layered, disjointed, a patchwork. In front and to the sides of the building can be seen the foundations of Königsberg Castle. The House of Soviets strongly suggests an architectural uncanny as a "double" of its antecedent. And that the new Soviet building was referred to as a "Dom", a house, which replaced the house of Königsberg's Prussian aristocracy reinforces its haunted quality.

Across Moskovski Prospect, directly in front of the House of Soviets, is Lower Pond, what the German's called the Schlossteich, the Castle Lake. It was surrounded by hotels and cafes and was a recreation and leisure area. It is still a popular place for Kaliningraders to take a walk, but the buildings are gone. The view from the roof of the House of Soviets reveals the absence of the city, one of its hallmarks.

But the most striking scene atop the House of Soviets lies behind it, towards a channel of the Pregolya River. Here can be viewed the unlikely confluence of the German past and themed present of Kaliningrad. In the foreground is the Konigsberg Cathedral, the last bit of the medieval city extant. Attached to the cathedral is the pillared tomb of philosopher Immanuel Kant, who lived his whole life in Königsberg and was a professor at the Albertina, now called Immanuel Kant Baltic Federal University.

The Königsberg Cathedral is on what is now called Kant Island, what the German's called the Kneiphof. It was densely packed with buildings, and now is an urban park. Again, absence is revealed in the cityscape, caused by historical rupture.

Beyond the Cathedral, lining the banks of the river, can be seen the Fisherman's Village, a modern interpretation of Königsberg's architecture. It is comprised of a series of hotels and eateries, gabled and decorated like the disappeared architecture of the city's past. It 
is the most prominent themed space in Kaliningrad, though many buildings dot the city, recalling the German era.

Illustration 5: Feeling Kaliningrad from the rooftop

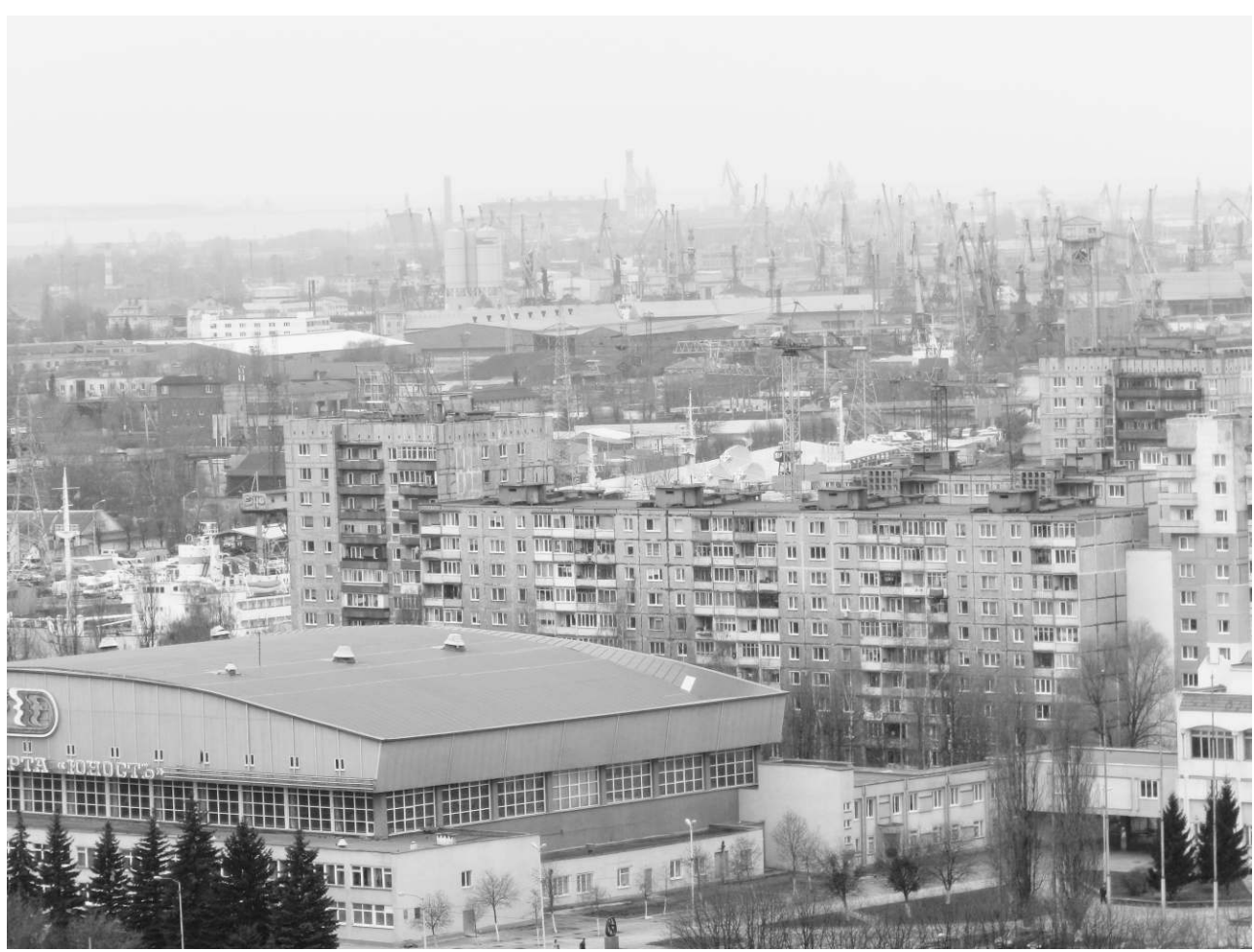

Source and copyright: @ Michael Amundsen.

The panorama seen from the House of Soviets' roof reveals Kaliningrad's ruptured history, expressed in the built environment and the building itself as the epicenter of the city's architectural distinctiveness. In terms of urban exploration, trespassing in the building provides both novel sensory insights and matchless views of Kaliningrad's urban spaces.

Architecture can articulate experiences of being-in-the world and strengthen our sense of reality and self, not make us inhabit worlds of mere fabrication and fantasy (Pallasmaa, 2012). Speaking with Maria and Veronika over coffee after exploring the House of Soviets, we discussed the experience. When we were on the roof, Maria said something that intrigued me, "Now I know my home." I asked her to elaborate on this statement. She explained that the House of Soviets had been a presence throughout her life. In her childhood, she thought the place a "haunted house", a "monster", which dominated the landscape. Going through the building slowly, deliberately, she appreciated its form and also the view from the rooftop which allowed her to see Kaliningrad from a wholly new perspective. But also she liked the fact that "the people", including herself, had found their way into the structure for drinking bouts and making graffiti "making it our own". I asked her about the vandalism. "Who cares?" she said. "What's the difference? The building will never be used and now it's turning into something else."

As Maria explained, reaching the top of the building allowed her to see the city in a new way, but also extended her senses into the cityscape, appreciating the overall qualities of her home and its historical layers. Exploring the building also encouraged an encounter 
with the self, of her personal history and its relationship with the structure. The ruined structured helped her to understand her own life history and that of her hometown.

I asked Veronika, "suppose the building had been finished and was being used, do you think you would like it?" Her answer was an equivocal, "well perhaps, but we'd never get on the roof!" She added that exploring the inside of the building was "romantic" and promoted an imagination of "what could have been" and that the building is "a lesson in failure". "It reminds me that my parents and grandparents gave their lives to this system and it ended with a whimper and nothing". She noted that her grandfather had fought in the Great Patriotic War, which allowed Kaliningrad to become part of the Soviet Union and then Russia. For her, the House of Soviets was "sad" and reflects loss. "I had a happy Soviet childhood", she added.

Both Maria and Veronika noted the dust and musty odor as primary sensory affects in the House of Soviets. They also mentioned the debris, asbestos and broken windows as salient physical aspects of exploring the building. The view from the rooftop allowed them to see a panorama of their hometown, which they had never seen before.

41 Maria said of the House of Soviets, "as it falls apart, it becomes beautiful." I asked her what she meant by this. She explained "it's beautiful because it's real...and reminds me of so much." She added that exploring the building was important, to "get a sense of what it's like inside".

The comments of Maria and Veronika point to appreciating the ruined form of the House of Soviets from the Pallasmaanian notion of sixth sense. For both of them, exploring the structure promoted atmospheres that reinforced a sense of reality and the self. As a building designed to stand against the "terror of time" and an imposing structure meant to reflect an omnipotent and panoptical political system, its ruined form has found quite different meanings. For Maria and Veronika, its atmospheres promoted memory and emotion and a connection between the self and the landscape. Exploring the building and its haptic qualities reinforced truths about the body as repository of memories and of its mortality.

Urban exploration in the House of Soviets breached the forbidding edifice of "focused vision", allowing for an experience of participation as "insiders", embodied and emotive whereby as Pallasmaa has noted "a fusion takes place; I enter the space and the space enters me" (Pallasmaa, 2016, p. 2). This experience of mood is sensed and not intellectualized. Later, it can be described, but this is a reflection on feelings engendered in space. We do not observe an atmosphere, it embraces us and guides our senses and feelings.

\section{Conclusion}

Goethe called architecture "frozen music", and, as it has been said "music is all atmosphere." This points to the importance that atmospheres play in the meaning of architectural space. The House of Soviets was intended to be modernist, aloof and commanding. It is now more akin to punk rock and apropos of a do-it-yourself art form, it engages with the masses in ways that its architect Yulian Shvartsbreim could never have imagined. Far from projecting the dogma of communism from an imposing formalism, the building is falling to pieces and Kaliningrad's residents and others connect with it 
directly by walking through its derelict spaces, drinking there and spraying its walls with graffiti. In so doing, they discover themselves and their hometown.

The House of Soviets is a metonymy for Kaliningrad, not only because of its unusual composition and prominent location. The visitor to Kaliningrad cannot help but feel its atmosphere of contingency. Because of its history and built environment, Kaliningrad lacks a sense of permanence. As a spoil of war and a Russian space surrounded by nations of the European Union, Kaliningrad in many ways feels like a place that should not be there at all. The fact that German culture and political life occupied this space for 700 years and then vanished reinforces this notion. So does the housing stock in the city, which is prefabricated, past its useful lifespan and falling apart. So does the House of Soviets.

The terror of time is a palpable feeling in Kaliningrad. The ruined House of Soviets is a locus of this feeling. For my informants, entering this space suggested the passing of time, their personal and family history, the political history of their homeland and their own human mortality. The sixth sense atmospheres of the building, appreciated instantly, without reflection and intellectualizing were formed from the ensemble qualities of the ruin promoting feelings of loss, time and frailty. Being in the ruin is a haptic encounter with rough surfaces of decaying concrete, embodied movement through decrepitude and reflexivity. In this sense, the House of Soviets as a ruin is indeed a work of art, changing through its engagement with the effects of weather, entropy and those who visit it. The ruin is beautiful, romantic and haunting. It creates existential microcosms and embodied representations of the world (Pallasmaa,2000). In an extraordinary dialectic, the ruined form of the House of Soviets promotes, to quote Pallasmaa, a sense of "depth, sensory invitation, discovery, mystery and shadow" (Pallasmaa, 2000, p. 1) that its originally planned form could never have allowed. As a ruin, the building has found success and purpose.

Atmosphere is a set of perpetually unfolding and intersecting materialities (McCormack 2008, p. 415). The House of Soviets' atmosphere extends into the cityscape of Kaliningrad and into the people in its presence. Matter, weathering and decay strengthen the experience of time, causality and reality (Pallasmaa, 2000). The prominence of this building, located in the city centre with no other structures competing for human attention, brings its atmospheres into the everyday lives of citizens. This could be said to be an atmosphere of "gloom". Indeed, the centre of Kaliningrad, largely empty since the war, ringed by gray apartment blocks, can be seen as a forbidding place. A brutalist, empty concrete structure does add to this sense.

But, as has been shown, for residents of Kaliningrad, their relationship with the House of Soviets is more nuanced. Outsiders like myself could see the structure as kitsch, in the sense that it is "so bad, it's good." This can be a kind of fetishizing of an exotic "otherness", a relic of the Soviet Union. For local people, this is not the case. The building is part of their lives, their memories, their sense of the passing of time, and who they are.

Urban exploration of such a place reveals its value. The original form of the House of Soviets suggested the timelessness of the world of ideas, a Platonism of abstraction away from the human experience of life. Exploring the building undermines an edifice of control and intimidation and "humanizes" the space. The uneven surfaces, musty smells, various life forms and dim natural light all confer an experience of nature and embodied knowledge. The building is being taken over by natural processes of time and weather. 
This rough material is promoting the "tactile values" of authentic art stimulating life enhancing sensations of touch (Montagu, 1986). Every day, the House of Soviets moves further from its "utopian" form of abstraction towards greater interiority, intimacy and belonging. In so doing, it promotes empathy for our fellow human beings and our common existential condition, our greatest real defence against the terror of time.

\section{BIBLIOGRAPHY}

Anderson, Ben. 2006. Becoming and being hopeful: towards a theory of affect. Environment and Planning D: Society and Space. vol. 24, p. 733-752.

Bille, Mikkel, Bjerregaard, Peter \& Sørensen, Tim Flohr. 2015. Staging atmospheres: Materiality, culture, and the texture of the in-between. Emotion, space and society. vol. 15, p. 31-38.

Boym, Svetlana. 2001. The Future of Nostalgia. New York: Basic.

DeSilvey, Caitlin \& Edensor, Tim. 2012. Reckoning with Ruins. Progress in Human Geography. vol. 37, $\mathrm{n}^{\circ} 4$, p. 465-485. DOI: 10.1177/0309132512462271.

Edensor, Tim. 2007. Sensing the ruin. Senses and Society. vol. 2, n² 2, p. 217-232.

Edensor, Tim. 2008. Walking through the Ruins. In: Ingold, Tim \& Vergunst, Jo Lee (eds.) Ways of Walking: Ethnography and Practice on Foot. Burlington: Ashgate. p. 123-142.

Edensor, Tim \& Sumartojo, Shanti. 2015. Designing Atmospheres: Introduction to Special Issue. Journal of Visual Communication. vol.14, $\mathrm{n}^{\circ}$ 3, p. 251-265.

Garrett, Bradley. 2013. Explore Everything: Place Hacking the City. London: Verso.

Harries, Karsten. 1982. Building and the Terror of Time. Perspecta. vol. 19, p. 58-69.

Howes, David. (ed.). 2009. The Sixth Sense Reader. London: Bloomsbury.

Le Corbusier. 1923. Vers une architecture. Paris: Crès.

McCormack, Derek P. 2008. Engineering Affective Atmospheres on the Moving Geographies of the 1897 Andrée Expedition. Cultural Geographies. vol. 15, n²4, p. 413-430.

Montagu, Ashley. 1986. Touching: The Human Significance of the Skin. New York: Harper \& Rowe.

Pallasmaa, Juhani. 2000. Hapticity and Time: Notes on a Fragile Architecture. Architectural Review. vol. 207, p. 78-84.

Pallasmaa, Juhani. 2012 [2005]. The Eyes of the Skin. Oxford: Wiley. $3^{\text {rd }}$ edition.

Pallasmaa, Juhani. 2014. Space, place and atmosphere. Emotion and peripherical perception in architectural experience. Lebenswelt. vol. 4, $\mathrm{n}^{\circ}$ 1, p. 230-245.

Pallasmaa, Juhani. 2016. The Sixth Sense. Crossing Worlds: Mathematical Logic, Philosophy, Art. Lecture notes retrieved from http://www.math.helsinki.fi/logic/CW_Pallasmaa.pdf

Schonle, Andreas. 2006. Ruins and History: Observations on Russian Approaches to Destruction and Decay. Slavic Review. vol. 65, n²4, p. 649-669. 
Simmel, Georg. 1959. The Ruin. In: Wolf, Kurt H. (ed.) Georg Simmel 1858-1918: A Collection of Essays with Translations and Bibliography. Columbus: Ohio State University Press. p. 259-266.

\section{NOTES}

1. Porter, Cole. 1936 [1956]. I've got under my skin (3'40). In: Sinatra, Frank. Songs for Swingin' Lovers. Capitol Records.

2. Translation from the original in French: "L'architecture est le jeu, savant, correct et magnifique des volumes sous la lumière. Nos yeux sont faits pour voir les formes sous la lumière ; les ombres et les clairs révèlent les formes."

\section{ABSTRACTS}

This article addresses the House of Soviets, the most prominent building in the centre of Kaliningrad, Russia. Using Juhani Pallasmaa's theory of "sixth sense", the building is seen through notions of atmospheres and diffusion, rather than the focused attention implied by its formalist construction. Local people have nicknamed the building the "monster" or "robot", for its giant size and forbidding appearance. However, its status as an urban ruin implies spatial and temporal meanings that have "humanized" the building. The article focuses on the experience of urban exploration in the House of Soviets for one afternoon in the spring of 2013 with two Kaliningrad residents. This paper avers that the changing form of the House of Soviets in its state of decay promotes its appreciation as a work of art as it falls apart. Decrepitude and pillage, vandalism and littering are reclaiming the space as it promotes sensory imagination and engagement with "the terror of time". The article includes photographs taken while exploring the building.

Cette publication porte sur la Maison des Soviets, le bâtiment le plus réputé au centre de Kaliningrad, en Russie. Par le biais de la théorie du sixième sens de Juhani Pallasma, cette construction est perçue à l'aide des concepts d'ambiances et de diffusion, plutôt que selon une attention portée sur sa construction formaliste. La population locale a surnommé ce bâtiment le «monstre » ou le « robot», de par sa taille géante et son apparence hostile. Toutefois, son statut de ruine urbaine implique des significations spatiales et temporelles qui l'ont « humanisé ». Cet article se concentre sur l'expérience d'exploration urbaine réalisée dans la Maison des Soviets lors d'un après-midi, en 2013, accompagné de deux habitants de Kaliningrad. Cette publication cherche à affirmer que la forme changeant de la Maison des Soviets, dans son état de délabrement, valorise sa reconnaissance en tant qu'œuvre d'art alors qu'elle s'effondre. La décrépitude et les pillages, le vandalisme et le dépôt d'ordures réhabilitent cet espace tout en mettant en avant l'imagination sensorielle et l'engagement envers la «terreur de l'époque ». Cet article inclut des photos prises lors de l'exploration du bâtiment. 
INDEX

Mots-clés: Maison des Soviets, sixième sens, ruine urbaine, détérioration, temps

Keywords: House of Soviets, sixth sense, urban ruin, decay, time

\section{AUTHOR}

\section{MICHAEL AMUNDSEN}

Michael Amundsen holds a doctorate from the School of Humanities at Tallinn University in Estonia. His work has been diverse and has looked at literature, especially the Beat Generation, and urban situations and spaces from busking to the architectural legacy of the former Soviet Union. He is the editor of Baltic Publishing, an academic publisher in Estonia, and is a journalist who has written for the Guardian and Financial Times among others. He has taught humanities and English literature at San Francisco State University, Tallinn University and the Estonian Academy of Art. He is currently teaching at the New College, School of Humanities, Arts and Cultural Studies at Arizona State University.

Contact: michael.amundsen@asu.edu 